\title{
Pengaruh Kreasi Media Debog terhadap Kemampuan Kreativitas Anak Usia 5-6 Tahun
}

\author{
Rahma Tika $^{1 凶}{ }^{1}$ Dadan Suryana ${ }^{1}$ \\ Pendidikan Anak Usia Dini, Universitas Negeri Padang, Indonesia(1) \\ DOI: $10.31004 /$ obsesi.v6i3.1747
}

\begin{abstract}
Abstrak
Kreativitas merupakan kemampuan seseorang dalam menciptakan sesuatu hal yang baru yang terwujud dalam suatu gagasan atau karya nyata. Penelitian ini bertujuan untuk melihat pengaruh kreasi media debog terhadap kemampuan kreativitas anak usia 5-6 tahun. Metode penelitian yang digunakan adalah eksperimen dengan desain quasy eksperiment. Sampel terdiri dari kelompok B1 dan kelompok B4 masing-masingnya berjumlah 18 orang anak. Teknik pengumpulan data digunakan tes perbuatan, berupa pernyataan sebanyak 5 butir pernyataan dan alat pengumpulan data digunakan lembaran pernyataan. Selanjutnya data diolah dengan uji perbedaan (t-test). Berdasarkan hasil penelitian penggunaan media debog melalui berkreasi terbukti dapat memberikan pengaruh terhadap kemampuan kreativitas dan memperkuat daya imajinasi anak dalam menciptakan sesuatu yang baru serta dapat memotivasi dan menarik minat anak dalam belajar. Kemudian dapat menciptakan pelaksanaan pembelajaran yang kreatif, inovatif dan menyenangkan dalam mengembangkan kualitas pembelajaran di sekolah. Dengan demikian berkreasi menggunakan media debog memberi pengaruh yang signifikan terhadap kemampuan kreativitas anak usia 5-6 tahun.
\end{abstract}

Kata Kunci: kreasi media debog; kemampuan kreativitas; anak usia 5-6

\begin{abstract}
Creativity is a person's ability to create something new that is manifested in an idea or real work. This study aims to see the effect of debug media creation on the creativity ability of children aged 5-6 years. The research method used is an experiment with a quasi-experimental design. The sample consisted of group B1 and group B4 each of which amounted to 18 children. The data collection technique used an action test, in the form of a statement of 5 statement items and the data collection tool used a statement sheet. Furthermore, the data is processed by the difference test (t-test). Based on the results of research, the use of debug media through creativity has been proven to have an influence on creativity abilities and strengthen children's imagination power in creating something new and can motivate and attract children's interest in learning. Then it can create creative, innovative and fun learning implementations in developing the quality of learning in schools. Thus, being creative using debog media has a significant influence on the creative abilities of children aged 5-6 years.
\end{abstract}

Keywords: debog media creations; creativity ability; children aged 5-6

Copyright (c) 2021 Rahma Tika, Dadan Suryana.

$\triangle$ Corresponding author:

Email Address : rahmatika_2562@yahoo.com (Padang, Sumatera Barat, Indonesia)

Received 13 May 2021, Accepted 25 August 2021, Published 28 August 2021 


\section{PENDAHULUAN}

Dunia kognitif anak prasekolah bersifat kreatif, bebas dan fantastis. Menurut ( Mayar, 2019) menyatakan kreativitas mempunyai peran penting dalam perkembangan anak usia dini yang memiliki posisi dan kedudukan yag sama dengan pengembangan potensi kecerdasan lainnya. Hal ini dikarenakan kapasitas otak manusia pada usia dini berkembang sangat pesat. Kreativitas merupakan kemampuan seseorang untuk menciptakan sesuatu hal yang baru dan merupakan kombinasi dari beberapa informasi dan dapat yang diperoleh sebelumnya yang terwujud dalam karya nyata dan suatu gagasan (Nurani, 2020). Sternberg dalam Munandar (2014) Kreativitas merupakan titik pertemuan yang khas antara tiga atribut psikologis :Intelegensi, gaya kognitif dan kepribadian/motivasi.

Kreativitas berperan penting dalam mengembangkan potensi dalam diri dan suatu kebutuhan perwujudan potensi diri sebagai salah satu kebutuhan tertinggi seseorang (Suryana, 2020). Untuk mengembangkan seluruh perkembangan anak agar berkembang secara optimal dan anak menjadi kreatif dan aktif dapat dilakukan melalui pembelajaran anak usia dini sehingga anak mampu memecahkan ragam permasalahan yang dialami dalam kehidupan. Kemampuan ini dikenal dengan istilah kreativitas. Salah satu tujuan pendidikan yaitu menumbuh kembangkan kreativitas anak yang dapat dieksplorasi dan dirancang melalui kegiatan belajar sambil bermain (Mayar, 2019). Dalam menumbuh kembangkan kreativitas anak, salah satu yang sangat berpengaruh adalah kondisi lingkungan. Lingkungan pengap, sempit dan menjemukan akan terasa muram anak menjadi kurang semangat dalam mengumpukan ide cemerlang. Sehingga dengan kodisi lingkungan yang tidak mendukung kreativitas anak dengan sendirinya akan mati (Rachmawati, 2017).

Oleh karena itu pada pembelajaran anak usia dini di upayakan dapat memberikan layanan khusus pada anak yang juga memiliki kreativitas dan talenta yang berbeda supaya tujuan pembelajaran dapat di tujukan ke arahkan yang lebih baik. Lingkungan pembelajaran yang sengaja dirancang dan untuk merangsang memunculkan anak berprilaku kreatif biasanya akan mestrimulasi anak berpikir kreatif. Dalam menciptakan lingkungan yang kreatif pada anak dapat disesuaikan dengan rentang usia perkembangan anak, cara mereka belajar dan berpikir. Sehingga dapat pengembangkan kreativitas anak. Lingkungan yang dapat mendukung kreativitas dimana anak terdorong untuk belajar, bereksplorasi, berpikir, mengamati, merefleksikan, bermain dan mengajukan pertanyaan yang tidak biasa yang mana anak mampu untuk membuat koneksi antara bahan pembelajaran, lingkungan sekitarnya (Wahyuningsih , 2020). Dalam berkreasi, tidak hanya memerlukan bahan dan peralatan yang mahal namun dengan pemanfaatan kearifan, potensi lokal dan sumber daya sekitar akan lebih bermanfaat dan bermakna bagi anak (Astuti , 2019).

Pengimplementasian kreativitas dalam sistem pembelajaran diharapkan peserta didik nanti dapat menuangkan ide-ide baru yang berbeda dalam pemecahan masalah dihadapi sehingga kaya dengan ide-ide yang progresif dan divergen yang nantinya dapat berkompetensi dan bersaing secara global yang selalu berubah (Suryana, 2020). Guru prasekola harus menyediakan materi yang kaya sehingga dapat mengerakkan imajinasi anak, memberi kesempatan bagi anak untuk mengekspresikan ide-ide mereka, kemudian menghargai individualitas dan mendorong perspektif yang berbeda (Dere, 2019).

Penelitian yang dilakukan oleh Mahardika (2019) menunjukan pengembangan kreativitas anak usia dini sangatlah penting karena dengan adanya permainan yang mendukung kreativitas menjadikan anak mampu mengekspresikan imajinasinya dengan seni gagasan atau produk baru, anak dapat mengubah bentuk yang sudah ada menjadi bentuk lain, anak dapat berkarya tidak sama dengan hasil teman-temanya serta anak dapat menambah bentuk baru pada karya yang dibuat, mengagunkan media yang ada. Selanjutnya penelitian yang dilakukan oleh Marwiyati \& Istiningsih (2020) menunjukan kreativitas anak dapat dirangsang melalui pembelajaran saintifik karena anak lebih mandiri, percaya diri, berani berpendapat, dan rasa ingin tahu yeng tinggi sebagai ciri kreatif. Kemudian penelitian yang dilakukan oleh Debeturu \& Wijayaningsih (2019) bahwa kreativitas dapat membantu 
anak menemukan ide-ide, serta berimajinasi dalam membuat sesuatu hal yang baru dan pemberian rangsangan kreativitas harus diberikan pada anak semenjak anak masih berusia dini

Berdasarkan fenomena di lapangan pada kenyataannya terlihat sistem pendidikan anak masih banyak menerapkan metode konvensional. Berdasarkan observasi awal peneliti di Taman Kanak-kanak Inayah menunjukan perkembangan anak sudah berkembangan dengan baik di berbagai aspek seperti: nilai agama dan moral, kognitif, bahasa, sosialemosional, dan fisik-motorik. Namun kemampuan kreativitas anak belum berkembang dengan baik. Anak masih kurang mampu menuangkan ide berdasarkan kreasinya sendiri terlihat anak dominan meniru apa yang dicontohkan guru atau temannya. Selanjutnya dalam pembelajaran anak sering menggunakan lembaran kerja anak, hal ini membuat kreativitas anak hanya duduk diam mengerjakan kegiatan yang sudah disediakan guru. Kemudian imajinasi dan ide-ide kreatif anak dalam memanfaatkan bahan alam lingkungan sekitarnya belum berkembang dengan baik.

Media pembelajaran yang baik yaitu media yang memberi kesempatan pada anak untuk mendapatkan juga memperkaya pengetahuan secara langsung (Nurhafizah, 2018). Melalui pembelajaran yang mengaktifkan seluruh panca indera anak mendapat pengalaman langsung dari aktivitas belajaranya akan menjadikan struktur otak berkembang dengan baik (Suryana, 2014). Media pembelajaran Dalam pembelajaran anak usia dini diperlukan pembelajaran bermakna sebagai proses pembelajaran yang akan menjadi landasan pengetahuan dalam menghadapi tahap perkembangan berpikir yang pada akhirnya akan memberikan landasan yang kokoh dalam menghadapi tahap pendidikan lanjutan (Suryana, 2017)

Dalam upaya membantu perkembangan kreativitas anak merupakan segala sesuatu yang dapat dijadikan bahan (soft-ware) dan alat (hardware) untuk bermain yang membuat AUD mampu memperoleh pengetahuan, keterampilan, dan menentukan sikap (Latif, 2016). Salah satu sumber belajar dan komponen terpenting dalam proses pendidikan anak usia dini diantaranya lingkungan, dimana lingkungan yang dimaksud mencakup segala sumber yang ada dalam lingkungan anak seperti lingkungan keluarga, rumah, kebun, persawahan dan lain-lain sehingga mendukung dan akan mendorong anak untuk menunjukkan aktivitas belajarnya (Yaswinda, 2018).

Dalam upaya membantu perkembangan kreativitas anak perlu di stimulasi dengan berbagai kegiatan yang menarik minat anak. Salah satu kegiatan dan media yang dapat menarik minat dan perhatian anak adalah berkreasi dengan menggunakan media debog yaitu pelepah pisang kering media ini lebih praktis mudah di dapat dan ramah lingkungan. Selain itu juga media debog mempunyai tekstur yang unik dan sebelumya sudah di warnai dengan berbagai warna yang menarik. Disamping itu penggunaan media debog sangat relevan dengan lingkungan taman kanak-kanak inayah Pasaman Barat yang mana banyak ditumbuhi pohon pisang, sehingga dengan memanfaatkan media debog anak akan langsung berinteraksi dengan alam.

Harijati (2014) mengungkapkan bahwa media debog (bahasa jawa) adalah limbah pelepah pisang kering yang dapat menghasilkan banyak hal positif. Pelepah pisang sebagai bahan baku pembuatan kerajinan adalah pelepah pisang yang telah kering. Media debog adalah pelepah pisang kering yang dapat dijadikan sebagai bahan baku pembuatan kerajinan, keterampilan atau berbagai kreasi. Media debog mudah dimanfaatkan dan dibentuk sesuai dengan keiginan, sehingga media debog dapat dikreasikan oleh anak menjadi beberapa bentuk kreasi yang indah dan menarik seperti kolase, tas, tempat pensil dan bingkai foto. Dengan demikian berkreasi menggunakan media debog akan merangsang kemampuan kreativitas anak yang merupakan media alam dan dapat dimanfaatkan serta dikreasikan sedemikian rupa oleh anak sebagai media permainan dan dapat digunakan oleh anak sebagai media pembelajaran. 
Kesamaan penelitian ini dengan penelitian sebelumnya yaitu membahas tentang kreativitas dan perbedaannya penelitian ini melihat pengaruh kreasi media debog terhadap kemampuan kreativitas anak. Sasaran dalam penelitian ini adalah anak usia 5-6 tahun. Tujuan untuk mengetahui pengaruh kreasi media debog terhadap kemampuan kreativitas anak usia 5-6 Tahun. Urgensi penelitian ini memberi kesempatan pada anak untuk bereksplorasi, berkreasi serta mempunyai peran aktif dalam mengali informasi tentang sesuatu hal yang baru melalui lingkungan sekitar anak sehingga kemampuan kreativitas anak dapat berkembang dengan baik.

\section{METODOLOGI}

Berdasarkan permasalahan yang diteliti maka jenis penelitian ini adalah eksperimen dengan desain penelitian Quasi experiment. Menurut (Sugiyono, 2015:13) metode eksperimen adalah metode penelitian yang digunakan untuk mencari pengaruh perlakuan tertentu terhadap yang lain dalam kondisi yang terkendalikan. Populasi dalam penelitian ini adalah Taman Kanak-kanak Inayah. Teknik pengambilan sampel yang dilakukan dalam penelitian ini adalah teknik cluster sampling. Adapun yang menjadi subjek peneliti yaitu anak kelompok usia B di Taman Kanak-kanak Inayah berjumlah 36 orang. Kelompok B1 beranggota 18 orang anak sebagai kelas Eksperimen dan kelompok B4 sebanyak 18 orang anak yang dijadikan sebagai kelas kontrol.

Teknik analisis data yang digunakan dalam penelitian ini adalah membandingkan perbedaan dari dua rata-rata nilai, sehingga dilakukan dengan uji t $(t$-tes). Untuk prasyarat uji hipotesis dilakukan uji normalitas menggunakan Liliefors dan uji homogenitas menggunakan uji Bartlett. Untuk dapat menarik kesimpulan dari hasil penelitian, dilakukan uji hipotesis dengan menggunakan uji t. Sebelum melakukan uji t terlebih dahulu dilakukan uji normalitas dan uji homogenitas terhadap hasil penelitian. Desain penelitian diilustrasikan pada gambar 1.

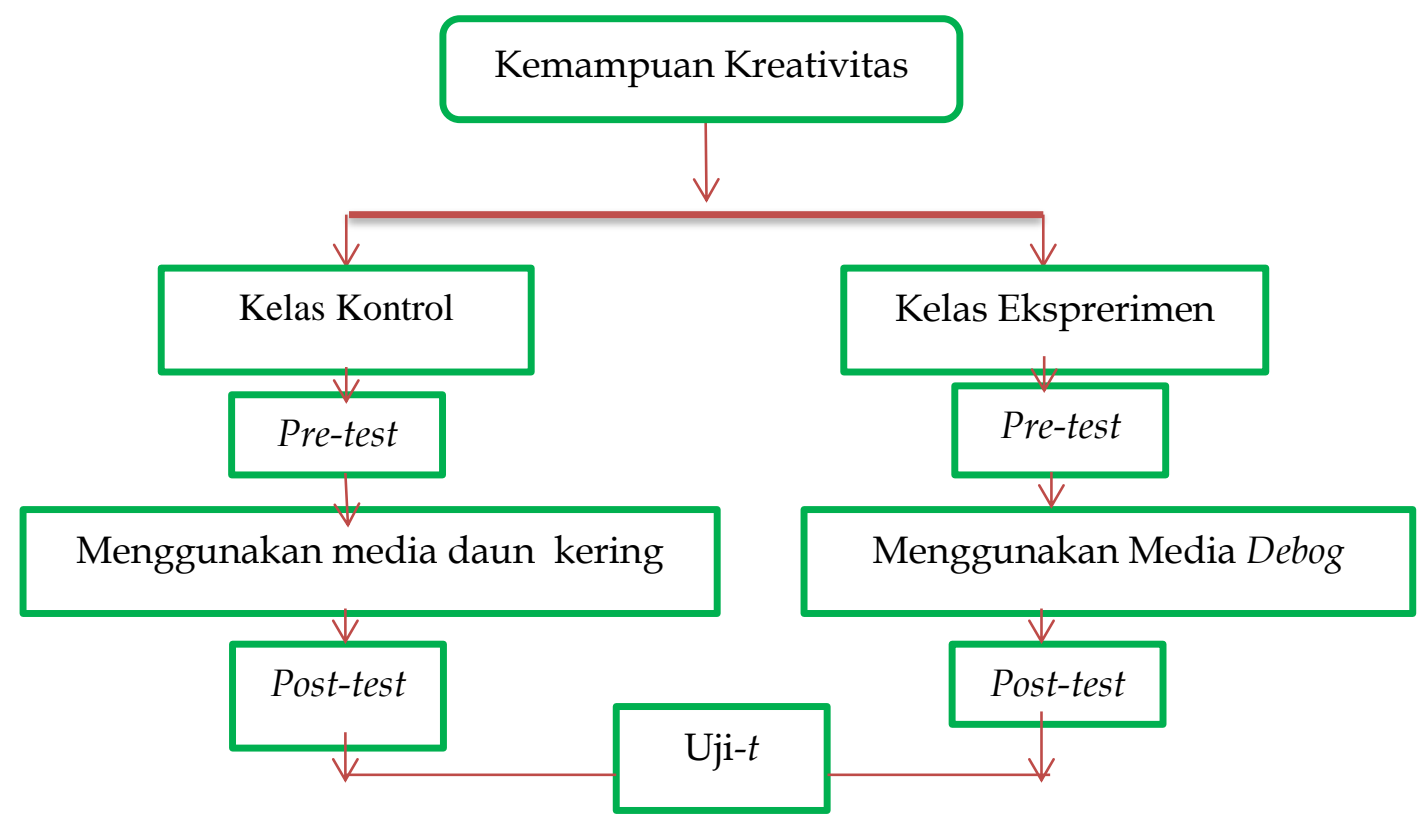

Gambar 1. Bagan Alur Penelitian

\section{HASIL DAN PEMBAHASAN}

Data yang dideskripsikan dalam penelitian ini terdiri dari dua kelompok yaitu data tentang hasil pretest (kemampuan awal) kemampuan kreativitas anak sebelum diberikan treatment terhadap kelompok eksperimen dan kelompok kontrol yang ditampilkan pada tabel 1. 
Tabel 1. Rekapitulasi Hasil Pretest Kemampuan Kreativitas Anak di Kelas Eksperimen dan Kelas Kontrol

\begin{tabular}{lcc}
\hline Variabel & \multicolumn{2}{c}{ Kelompok } \\
& Eksperimen & Kontrol \\
\hline $\mathrm{N}$ & 18 & 18 \\
Nilai tertinggi & 68 & 64 \\
Nilai terendah & 52 & 52 \\
Jumlah nilai & 1108 & 1076 \\
Median & 59,75 & 58,64 \\
Rata-rata & 61,5 & 59,7 \\
SD & 5,3 & 3,8 \\
SD $^{2}$ & 28,69 & 15,06 \\
\hline
\end{tabular}

Berdasarkan tabel 1, kelas eksperimen dengan jumlah anak 18 orang memperoleh nilai tertinggi 68 dan nilai terendah 52. Dari nilai anak kelas eksperimen ini diperoleh jumlah nilai secara keseluruhan yaitu 1108, dengan rata-rata nilainya sebesar 61,5, standar deviasinya 5,3 dan nilai variansnya 28,69. Dan kelas kontrol dengan jumlah anak 18 orang memperoleh nilai tertinggi 64 dan nilai terendah 52. Dari nilai anak kelas kontrol ini diperoleh jumlah nilai secara keseluruhan yaitu 1076, dengan rata-rata nilainya sebesar 59,7, standar deviasinya 3,8 dan nilai variansnya 15,06 .

Tabel 2. Rekapitulasi Hasil Post-test Kemampuan Kreativitas Anak di Kelas Eksperimen Dan Kelas Kontrol

\begin{tabular}{lcc}
\hline Variabel & \multicolumn{2}{c}{ Kelompok } \\
& Eksperimen & Kontrol \\
\hline N & 18 & 18 \\
Nilai tertinggi & 96 & 84 \\
Nilai terendah & 80 & 64 \\
Jumlah nilai & 1580 & 1320 \\
Median & 87 & 73,5 \\
Rata-rata & 87,7 & 73,3 \\
SD & 4,89 & 6,79 \\
SD & 23,95 & 46,22 \\
\hline
\end{tabular}

Tabel 2 menunjukkan, kelas eksperimen dengan jumlah anak 18 orang memperoleh nilai tertinggi 96 dan nilai terendah 80. Dari nilai anak kelas eksperimen ini diperoleh jumlah nilai secara keseluruhan yaitu 1580, dengan rata-rata nilainya sebesar 87,7 standar deviasinya 4,89 dan nilai variansnya 23,95. Dan kelas kontrol dengan jumlah anak 18 orang memperoleh nilai tertinggi 84 dan nilai terendah 64. Dari nilai anak kelas kontrol ini diperoleh jumlah nilai secara keseluruhan yaitu 1320, dengan rata-rata nilainya sebesar 73,3, standar deviasinya 6,79 dan nilai variansnya 46,22.

Berdasarkan uji normalitas kelas eksperimen dan kelas kontrol diperoleh harga $\mathrm{L}_{0}$ dan $\mathrm{L}_{t}$ pada taraf nyata 0,05 untuk $\mathrm{N}=18$ seperti pada tabel 3. Berdasarkan tabel 3, kelas eksperimen nilai $L_{\text {hitung }} 0,1785$ lebih kecil dari $L_{\text {tabel }} 0,200$ untuk $\alpha=0,05$. Dengan demikian, nilai kelompok eksperimen berasal dari data yang berdistribusi normal. Untuk kelas kontrol, diperoleh $L_{\text {hitung }} 0,1292$ lebih kecil dari $L_{\text {tabel }} 0,200$ untuk $a=0,05$. Ini berarti bahwa data kelompok kontrol berasal dari data yang berdistribusi normal.

Pengujian persyaratan yang kedua adalah pengujian homogenitas dengan menggunakan uji Bartlett. Pengujian ini bertujuan untuk mengetahui apakah data berasal dari kelompok yang homogen, antara kelas eksperimen dan kelas kontrol. Selengkapnya dapat dilihat pada tabel 4 . 
Tabel 3. Hasil Perhitungan Uji Liliefors Kelas Eksperimen dan Kelas Kontrol (pretest)

\begin{tabular}{llccccl}
\hline No & Kelas & $\mathbf{N}$ & $\mathbf{A}$ & $\mathbf{L}_{\mathbf{0}}$ & $\mathbf{L}_{\mathbf{t}}$ & Keterangan \\
\hline 1 & Eksperimen & 18 & 0,05 & 0,1785 & 0,200 & Normal \\
2 & Kontrol & 18 & 0,05 & 0,1292 & 0,200 & Normal \\
\hline
\end{tabular}

Tabel 4. Hasil Uji Homogenitas Kelas Eksperimen dan Kelas Kontrol (pretest)

\begin{tabular}{lcccc}
\hline Kelas & A & $X^{2}$ hitung & $X^{2}$ tabel & Kesimpulan \\
\hline Eksperimen & & 1,565 & 3,841 & Homogen \\
Kontrol & 0,05 & 1,56 & & \\
\hline
\end{tabular}

Berdasarkan tabel 4, $X^{2}$ hitung kelas eksperimen dan kelas kontrol lebih kecil dari $X^{2}$ tabel $\left(X^{2}\right.$ hitung $<X^{2}$ tabel), berarti kelas eksperimen dan kelas kontrol memiliki varians yang homogen.

Untuk menguji hipotesis digunakan t-test. Dari hasil uji hipotesis dengan menggunakan t-test diperoleh hasil sebagaimana ditampilkan pada tabel 5 .

Tabel 5. Hasil Perhitungan Pengujian dengan t-test

\begin{tabular}{|c|c|c|c|c|c|c|}
\hline No & Kelompok & $\mathbf{N}$ & $\begin{array}{l}\text { Hasil } \\
\text { Rata-rata }\end{array}$ & $t_{\text {hitung }}$ & $\begin{array}{c}t_{\text {tabel }} \\
\text { a } 0,05\end{array}$ & Keputusan \\
\hline 1 & Eksperimen & 18 & 61,5 & \multirow{2}{*}{1,125} & \multirow{2}{*}{2,03224} & \multirow{2}{*}{ Terima $\mathrm{H}_{0}$} \\
\hline 2 & Kontrol & 18 & 59,7 & & & \\
\hline
\end{tabular}

Berdasarkan tabel 5, dk $\left(\mathrm{N}_{1}-1\right)+\left(\mathrm{N}_{2}-1\right)=34$. Dalam tabel df untuk taraf nyata a 0,05 didapat harga $t_{\text {tabel }}$ 2,03224, maka dapat dikatakan bahwa hipotesis $\mathrm{H}_{1}$ ditolak atau $\mathrm{H}_{0}$ diterima. Dapat disimpulkan bahwa tidak terdapat perbedaan yang signifikan antara hasil pretest (kemampuan awal) anak di kelas eksperimen dan kelas kontrol dalam kemampuan kreativitas anak.

Data hasil post-test kemampuan kreativitas pada anak di kelas eksperimen dan kelas kontrol diolah untuk menentukan uji normalitas. Pada uji normalitas ini, digunakan uji Liliefors seperti yang dikemukakan pada teknik analisis data.

Tabel 6. Hasil Perhitungan Uji Liliefors Kelas Eksperimen dan Kelas Kontrol (post-test)

\begin{tabular}{llccccl}
\hline No & Kelas & $\mathbf{N}$ & $\alpha$ & $\mathbf{L}_{0}$ & $\mathbf{L}_{\mathrm{t}}$ & Keterangan \\
\hline 1 & Eksperimen & 18 & 0,05 & 0,1361 & 0,200 & Normal \\
2 & Kontrol & 18 & 0,05 & 0,1853 & 0,200 & Normal \\
\hline
\end{tabular}

Berdasarkan tabel 5, kelas eksperimen nilai $\mathrm{L}_{\text {hitung }}$ 0,1361 lebih kecil dari $\mathrm{L}_{\text {tabel }}$ 0,200 untuk $\alpha=0,05$. Dengan demikian, nilai kelompok eksperimen berasal dari data yang berdistribusi normal. Untuk kelas kontrol, diperoleh $\mathrm{L}_{\text {hitung }} 0,1853$ lebih kecil dari $\mathrm{L}_{\text {tabel }} 0,200$ untuk $\mathrm{a}=0,05$. Ini berarti bahwa data kelompok kontrol berasal dari data yang berdistribusi normal.

Tabel 7. Hasil Uji Homogenitas Kelas Eksperimen dan Kelas Kontrol (post-test)

\begin{tabular}{lcccl}
\hline \multicolumn{1}{c}{ Kelas } & $\alpha$ & $X^{2}$ hitung & $X^{2}$ tabel & Kesimpulan \\
\hline Eksperimen & & & & \\
Kontrol & 0,05 & 1,842 & 3,841 & Homogen \\
\hline
\end{tabular}


Pengujian persyaratan yang kedua adalah pengujian homogenitas dengan menggunakan uji Bartlett. Pengujian ini bertujuan untuk mengetahui apakah data berasal dari kelompok yang homogen, antara kelas eksperimen dan kelas kontrol. Berdasarkan tabel 7, $X^{2}$ hitung kelas eksperimen dan kelas kontrol lebih kecil dari $X^{2}$ tabel $\left(X^{2}\right.$ hitung $<X^{2}$ tabel), berarti kelas eksperimen dan kelas kontrol memiliki varians yang homogen.

Setelah uji normalitas dan uji homogenitas, kemudian dilanjutkan dengan pengujian t-test, untuk mengetahui apakah terdapat perbedaan yang signifikan untuk kedua kelompok Untuk menguji hipotesis digunakan t-test. Dari hasil uji hipotesis dengan menggunakan $t$-test diperoleh hasil sebagaimana dapat dilihat pada tabel 8 .

Tabel 8. Hasil Perhitungan Pengujian dengan t-test

\begin{tabular}{llllccc}
\hline No & Kelompok & $\mathbf{N}$ & $\begin{array}{l}\text { Hasil } \\
\text { Rata-rata }\end{array}$ & \multicolumn{2}{c}{$\begin{array}{l}t_{\text {hitung }} \\
t_{\text {tabel }} \\
\mathbf{a ~ 0 , 0 5}\end{array}$} & Keputusan \\
\hline $\mathbf{1}$ & Eksperimen & 18 & 87,7 & 7,093 & 2,03224 & Tolak $\mathrm{H}_{0}$ \\
$\mathbf{2}$ & Kontrol & 18 & 73,3 & 7,093 & & \\
\hline
\end{tabular}

Berdasarkan pada tabel 8, dk $\left(\mathrm{N}_{1}-1\right)+(\mathrm{N} 1)=34$. Dalam tabel df untuk taraf nyata a 0,05 didapat harga tabel 2,03224, maka dapat dikatakan bahwa hipotesis $\mathrm{H}_{1}$ diterima atau $\mathrm{H}_{0}$ ditolak. Dapat disimpulkan bahwa terdapat perbedaan yang signifikan antara hasil post-test (hasil akhir) anak di kelas eksperimen dan kelas kontrol dalam kemampuan kreativitas anak.

Berdasarkan hasil pretest (sebelum diberikan treatment) kemampuan kreativitas yang diberikan pada kelas eksperimen dan kelas kontrol diperoleh angka rata-rata kelas eksperimen yaitu 61,5, dan angka rata-rata kelas kontrol yaitu 59,7. Berdasarkan hasil analisis data pretest yang telah dilakukan bahwa thitung sebesar 1,125dibandingkan dengan a 0.05 $(\mathrm{t}$ tabel $=2,032)$ dengan derjat kebebasan $\mathrm{dk}(\mathrm{N} 1-1)+(\mathrm{N} 2-1)=34$. Dengan demikian dapat dikatakan bahwa t hitung $<\mathrm{t}$ tabel yaitu 1,125 $<2,032$, maka dapat dikatakan bahwa hipotesis H1 ditolak dan H0 diterima. Dapat disimpulkan bahwa, tidak terdapat perbedaan yang signifikan antara hasil pretest kemampuan kreativitas pada anak kelas eksperimen dan kelas kontrol sebelum diberikan treatment. Ini berarti bahwa, kemampuan kreativitas pada pretest (kemampuan awal) sama atau tidak memiliki perbedaan yang signifikan.

Kemudian, berdasarkan hasil postest (hasil akhir) perkembangan kreativitas pada kelas eksperimen dan kelas kontrol diperoleh rata-rata kelas eksperimen 87,7 dan rata-rata kelas kontrol 73,3. Berdasarkan hasil analisis data postest yang telah dilakukan bahwa t hitung sebesar 7,093 dibandingkan dengan a 0.05 ( $\mathrm{t}$ tabel $=2,032)$ dengan derjat kebebasan $\mathrm{dk}(\mathrm{N} 1$ $1)+(N 2-1)=34$. Dengan demikian dapat dikatakan bahwa $t$ hitung $>t$ tabel yaitu 7,093 $>2,032$, maka dapat dikatakan bahwa hipotesis H1 diterima dan H0 ditolak. Dapat disimpulkan bahwa, terdapat perbedaan yang signifikan antara hasil postest kemampuan kreativitas anak kelas eksperimen dengan menggunakan kreasi media debog dan kelas kontrol dengan menggunakan kreasi media daun kering. Kreativitas adalah kemampuan berpikir ataupun melakukan tindakan yang bertujuan untuk mencari pemecahan sebuah kondisi ataupun permasalahan secara cerdas, berbeda, tidak umum orisinal, serta membawa hasil yang tepat dan bermanfaat (Mayar, 2020). Menurut Kiewra ((2016) empat faktor belajar di luar ruang kelas alami yang meningkatkan kreativitas dan imajinasi anak-anak terungkap: (a) ruang yang dapat diprediksi, (b) waktu yang cukup dan konsisten, (c) materi terbuka, dan (d) perhatian yang jeli yang mendukung permainan kreatif dan belajar. Harijati (2014) menyatakan bahwa media debog (bahasa jawa) adalah limbah pelepah pisang kering yang dapat menghasilkan banyak hal positif.

Pada saat peneliti menggunakan media debog (B1) Taman Kanak-kanak Inayah, semua anak terlihat begitu antusias dan semangat untuk mencobanya, karena media debog mempunyai daya tarik tersendiri sehingga dapat mengembangkan kemampuan kreativitas anak usia dini, media debog ini mudah untuk di kreasikan menjadi berbagai bentuk benda yang menarik dan unik seperti tas, kolase, tempat pensil, bunga. Kemudian memiliki 
bermacam-macam warna untuk menarik perhatian dan minat belajar anak sehingga anak bisa berkreasi dengan berbagai warna debog sesuai keinginan anak sehingga dapat merangsang daya imajinasi anak lebih berkembang dan kreatif. Kelas kontrol menggunakan media daun kering dalam mengembangkan kemampuan kreativitas. Anak terlihat kurang tertarik untuk melakukan kegiatan, karena anak sudah mulai bosan dengan pembelajaran yang menggunakan media tersebut karena sudah biasa digunakan, sehingga kurang merangsang daya imajinasi anak ,kemudian anak menjadi kurang kreatif. Kegiatan ini membuat anak kurang antusias dan tertarik dalam menuangkan kreativitasnya.

Jadi, hasil kemampuan kreativitas anak di kelas eksperimen lebih baik dari pada kemampuan kreativitas anak di kelas kontrol. Hal ini dapat dilihat dari nilai rata-rata anak kelas eksperimen yang lebih tinggi dari pada kelas kontrol. Maka, dapat disimpulkan bahwa penggunaan kreasi media debog mempengaruhi kemampuan kreativitas anak, serta memperkuat daya imajinasi anak dalam menciptakan sesuatu yang baru. Sehingga dapat menjadi acuan bagi peneliti untuk langkah selanjutnya dalam mengembangkan kemampuan kreativitas anak. Kemudian bagi guru dapat menciptakan pelaksanaan pembelajaran yang kreatif inovatif dan menyenangkan. Selanjutnya bagi sekolah dapat dijadikan rujukan dan pertimbangan dalam mengembangkan kualitas pembelajaran di sekolah.

\section{SIMPULAN}

Berdasarkan hasil penelitian yang telah dilakukan, maka dapat diambil kesimpulan bahwa terdapat pengaruh berkreasi menggunakan media debog terhadap kemampuan kreativitas anak usia 5-6 tahun. Hal ini terlihat anak mampu menuangkan imajinasi dan ideide kreatifnya dalam berkreasi dalam suatu karya nyata. Kemudian dapat memberi kesempatan pada anak untuk bereksplorasi, berkreasi serta mempunyai peran aktif dalam mengali informasi tentang sesuatu hal yang baru melalui lingkungan sekitar anak. Selain itu dapat memotivasi, menambah minat belajar sehingga kemampuan kreativitas anak dapat berkembang dengan baik.

\section{UCAPAN TERIMA KASIH}

Terimakasih kepada pembimbing yang sudah membantu memberikan masukan dan saran pada penelitian ini. Terimakasih kepada semua pihak yang telah membantu penulis sehingga penelitian ini dapat dipublikasikan serta keluarga yang telah memberikan dukungan kepada penulis dalam menulis artikel ini.

\section{DAFTAR PUSTAKA}

Astuti, R., \& Aziz, T. (2019). Integrasi Pengembangan Kreativitas Anak Usia Dini di TK Kanisius Sorowajan Yogyakarta. Jurnal Obsesi : Jurnal Pendidikan Anak Usia Dini, 3(2), 294. https://doi.org/10.31004/obsesi.v3i2.99

Debeturu, B., \& Wijayaningsih, E. L. (2019). Meningkatkan Kreativitas Anak Usia 5-6 Tahun melalui Media Magic Puffer Ball. Jurnal Obsesi : Jurnal Pendidikan Anak Usia Dini, 3(1), 233. https://doi.org/10.31004/obsesi.v3i1.180

Dere, Z. (2019). Investigating the creativity of children in early childhood education institutions. Universal Journal of Educational Research, 7(3), 652-658. https:// doi.org/10.13189/ujer.2019.070302

Harijati. (2014). d'Bogz Dolls. Surabaya:genta group.

Kiewra, C., \& Vaselkack, E. (2016). Playing with Nature : Supporting Preschoolers ' Creativity in Natural Outdoor Classrooms Christine Kiewra Dimensions Educational Research Foundation, USA Ellen Veselack. The International Journal of Early Childhood Environmental Education, 4(1), p. 71 International, 4(1), 71-96.

Latif, M. dkk. (2016). Orientasi Baru Pendidikan anak Usia Dini (Teori dan Praktek). Jakarta: Prenadamedia Grup. 
Mahardika, M. (2019). Pengembangan Kreativitas Anak Usia Dini di PAUD Kencana Sari 2 Cikidang Kecamatan Cilongok Kabupaten Banyumas. Institut Agama Islam Negeri Purwokerto.

Marwiyati, S., \& Istiningsih, I. (2020). Pembelajaran Saintifik pada Anak Usia Dini dalam Pengembangan Kreativitas di Taman Kanak-Kanak. Jurnal Obsesi : Jurnal Pendidikan Anak Usia Dini, 5(1), 135. https:// doi.org/10.31004/obsesi.v5i1.508

Mayar, F dkk. (2019). Peningkatan Kemampuan Kreativitas Anak melalui Kegiatan Menggambar Bebas Setiap hari di Taman Kanak-Kanak Darussalam Gadut. Jurnal Pendidikan Tambusai, 3(6), 1365-1373.

Mayar, Farida dkk. (2020). Peluang Wirausaha Baru Dalam Kreativitas Menggunting Berantai Di Taman Kanak Anugrah Sayang Ibu Di Kampuang Jua Kecamatan Sungai Limau. Jurnal Seni Rupa, 9(1), 40-43. https://doi.org/10.24114/gr.v9i1.17212

Munandar, U. (2014). Pengembangan Kreativitas Anak Berbakat. Jakarta: Rineka Cipta.

Nurani, Y. dkk. (2020). Memacu Kreativitas Melalui Bermain. Jakarta: Bumi Aksara.

Nurhafizah. (2018). Pelatihan Pembuatan Media Pembelajaran Anak Usia Dini Menggunakan $\begin{array}{llll}\text { Bahan Sisa. Jurnal } & \text { Pendidkan, }\end{array}$ https:// doi.org/10.35568/earlychildhood.v2i2b.288

Rachmawati, Y. dan E. K. (2017). Strategi Pengembangan Kreativitas Pada Anak. Jakarta: Kencana.

Rahayu, H. dkk. (2021). Meningkatkan Kreativitas Anak Usia Dini melalui Pembelajaran Gerak dan Lagu. Jurnal Obsesi: Jurnal Pendidikan Anak Usia Dini, 5(1), 832-840. https:// doi.org/10.31004/obsesi.v5i1.691

Sugiyono. (2015). Metode Penelitian Kuantitatif, Kualitatif Dan R \& D. Bandung: Alfabeta.

Suryana, D. (2014). Kurikulum pendidikan Anak Usia Dini berbasis Perkembangan Anak. Jurnal Pendidikan Dasar Dan Humaniora, 2(1), 65-72.

Suryana, D. dan N. R. (2020). Manjemen Pendidikan Anak Usia Dini (2nd ed.). Jakarta: Prenadamedia Grup.

Suryana, Dadan. (2017). Pembelajaran Tematik Terpadu Berbasis Pendekatan Saintifik di Taman kanak-kanak. Jurnal Pendidikan Usia Dini, 11(1), 67-82. https:// doi.org/10.21009/JPUD.111

Wahyuningsih, S., Pudyaningtyas, A. R., Hafidah, R., \& Munif, M. (2020). Jurnal Obsesi : Jurnal Pendidikan Anak Usia Dini Efek Metode STEAM pada Kreatifitas Anak Usia 5-6 Tahun Abstrak Abstact. 4(1), 295-301. https://doi.org/10.31004/obsesi.v4i1.305

Yaswinda, dkk. (2018). Pengembangan Bahan Pembelajaran Sains Berbasis Multisensori Ekologi Bagi Guru PAUD Kecamatan Tilatang Kamang Kabupaten Agam. Yaa Bunayya : Jurnal Pendidikan Anak Usia Dini. 